\title{
PENGARUH PERBANDINGAN IKAN KEMBUNG (Rastrelliger kanagurta) DENGAN SAYUR GONDA (Sphenoclea zeylanica Gaertner) TERHADAP KARAKTERISTIK BAKSO \\ Effect of Comparison of Mackerel (Rastrelliger kanagurta) with Gonda Vegetable (Sphenoclea zeylanica Gaertner) on Characteristics of Meatballs.
}

\author{
${ }^{1}$ Brogina Mayank Dini, ${ }^{2}$ Luh Putu Trisna Darmayanti*, ${ }^{2}$ I Ketut Suter \\ ${ }^{1}$ Mahasiswa Program Studi Ilmu dan Teknologi Pangan, Fakultas Teknologi Pertanian, Universitas \\ Udayana \\ ${ }^{2}$ Dosen Program Studi Ilmu dan Teknologi Pangan, Fakultas Teknologi Pertanian, Universitas Udayana \\ Kampus Bukit Jimbaran, Badung-Bali
}

\begin{abstract}
This research was conducted with the aim to determine the effect of comparison of mackerel with gonda vegetable on meatballs characteristics and get a comparison of mackerel with specific gonda vegetable that can produce meatballs with the best characteristics. This study uses a Completely Randomized Design (CRD) with treatment that is the comparison of mackerel with gonda vegetable consisting of 6 levels: 100\%: 0\%; 95\%: 5\%; 90\%: 10\%; $85 \%$ : 15\%; $80 \%$ : $20 \%$; $75 \%$ : $25 \%$. Each treatment was repeated 3 times so that obtained 18 units. The data is then analyzed by analysis of variance and if the treatment influences the proposed variable then it is continued by Duncan. The results showed that the comparison of mackerel and gonda vegetable had a very significant effect on water content, ash content, fat content, protein content, carbohydrate content, total chlorophyll content, antioxidant capacity, color (scoring), texture, aroma, overall acceptance and no significant effect for texture, aroma and taste. Comparison of $80 \%$ mackerel and $20 \%$ gonda vegetables had the best characteristics, with $62.99 \%$ water content, $1.56 \%$ ash content, $1.28 \%$ fat content, $8.75 \%$ protein content, $25.43 \%$ carbohydrate content, $18.39 \%$ total chlorophyll content, antioxidant capacity $25.63 \%$. Sensory properties obtained are color (rather green, rather like), texture (rather like), flavor (liked) and overall acceptance (like).

Keywords: Gonda vegetable, Mackerel, Meatballs
\end{abstract}

\section{PENDAHULUAN}

Ikan merupakan salah satu bahan makanan yang mengandung protein tinggi dan zat-zat yang dibutuhkan oleh tubuh manusia seperti vitamin A, vitamin B1 dan vitamin B2. Selain itu apabila dibandingkan dengan sumber protein lain seperti daging, dan susu, harga ikan relatif lebih murah (Lawang, 2013). Salah satu sumber daya alam yang potensial adalah ikan kembung yang merupakan salah satu komoditas yang sering dikonsumsi. Ikan ini memiliki rasa cukup enak dan gurih sehingga digemari oleh masyarakat (Thariq et al., 2014).

\footnotetext{
*Korespondensi penulis :

Email : trisnadarmayanti@unud.ac.id
}

Sampai saat ini, ikan kembung biasa diolah sebagai lauk yang dimasak secara utuh seperti dipeda, digoreng, dibakar, kuah pindang dan sebagainya. Penelitian yang telah dilakukan mengenai produk olahan ikan kembung meliputi ikan asin (Miefthawati et al., 2013), peda ikan kembung (Thariq et al ., 2014), surimi (Santoso et al., 2011), tepung ikan kembung (Haryati et al., 2006), cookies dengan subtitusi tepung ikan kembung (Rajagukguk, 2011) dan dibuat sebagai salah satu lauk untuk anak penderita autisme (Sari et al., 2013). Belum banyak penelitian yang mengkaji produk olahan lain seperti bakso dari ikan kembung. Bakso ikan yang biasa digunakan adalah 
ikan tuna ataupun ikan tinggiri, akan tetapi ikan kembung juga sangat berpotensi untuk diolah menjadi bakso karena daging ikan kembung mengandung protein tinggi, dan berkadar lemak rendah sehingga menguntungkan bagi kesehatan (Thariq et al., 2014).

Asal nama bakso terdiri dari dua suku kata yakni Bak dan So. Bak berarti Daging babi dan So yang berarti kuah. Sehingga dapat diartikan kuah dengan daging babi. Di dataran China, daging babi sudah biasa di kalangan penduduk. Namun, saat memasuki kawasan Indonesia, daging babi diganti dengan daging lainnya seperti daging sapi, ayam, dan ikan (seafood). Ada pula dalam Bahasa Hokkien yang secara harfiah Bak-So berarti "daging giling". Bakso merupakan jenis makanan yang tergolong paling populer di Indonesia dan pada umumnya dibuat dari daging sapi, tetapi ada pula dibuat dari jenis daging lain, termasuk daging ikan (Winarno dan Rahayu, 1994). Bakso ikan merupakan produk pangan yang terbuat dari bahan utama daging ikan yang dilumatkan, dicampur dengan bahan lain, dibentuk bulatan, dan selanjutnya direbus (Koswara et al., 2001).

Pada umumnya, kandungan klorofil yang terdapat pada bakso ikan belum tersedia, sehingga diperlukan fortifikasi dengan penambahan sayur gonda yang kaya akan klorofil. Selain klorofil, sayur gonda memiliki kandungan seperti vitamin A, B kompleks, kalsium, pospor, asam amino, dan $\beta$ karoten. Kandungan yang paling dominan pada sayur gonda adalah klorofil. Klorofil mudah diserap secara sempurna oleh tubuh, berkaitan dengan fungsi tersebut, klorofil banyak dimanfaatkan untuk membantu mengoptimalkan fungsi metabolik, sistem imunitas, meredakan radang, dan menyeimbangkan sistem hormonal, serta mengatasi beberapa jenis penyakit, seperti kanker, jantung, asma, jantung dan diabetes. Menurut Nurhadi (2011) sayuran berwarna lebih baik daripada sayuran yang tidak berwarna karena warna pada makanan memiliki efek fungsional bagi tubuh. Warna pada makanan memiliki khasiat masing-masing dan tergantung dari pigmen yang membentuk warna tersebut.

Gonda (Sphenoclea zeylanica Gaertner) merupakan salah satu sayuran tradisional yang dapat dimanfaatkan sebagai sumber pangan yang mengandung komponen bioaktif seperti klorofil yang berfungsi sebagai antioksidan dan dapat memberikan warna hijau pada makanan. Hasil analisis Cintari et al., (2013) menunjukkan bahwa tanaman gonda segar mengandung senyawa bioaktif sebagai antioksidan sehingga berpotensi untuk dikembangkan sebagai sumber pangan fungsional. Sayur gonda selama ini pemanfaatannya masih terbatas hanya untuk dikonsumsi sebagai hidangan sayuran. Gonda biasa diolah menjadi 
sayuran yang enak apabila diolah dengan bumbu yang khas seperti diplecing. Salah satu cara yang dapat dilakukan untuk meningkatkan umur simpan dan juga memberikan nilai tambah dari sayur gonda, maka dapat dimanfaatkan sebagai bahan dalam pembuatan bakso.

Penambahan sayur gonda pada bakso diharapkan dapat meningkatkan komponen bioaktif dari bakso. Berdasarkan uraian di atas maka dilakukan penelitian dengan tujuan mengetahui pengaruh perbandingan ikan kembung dengan sayur gonda terhadap karakteristik bakso dan menentukan perbandingan ikan kembung dengan sayur gonda yang tepat sehingga menghasilkan bakso dengan karakteristik terbaik.

\section{METODE PENELITIAN}

\section{Tempat dan Waktu Penelitian}

Penelitian ini dilakukan di Laboratorium Pengolahan Pangan, Laboratorium Analisis Pangan serta Laboratorium Rekayasa Proses Fakultas Teknologi Pertanian Universitas Udayana. Penelitian ini dilakukan pada bulan Agustus 2019 - Oktober 2019.

\section{Bahan dan Alat}

Bahan-bahan yang digunakan dalam penelitian terdiri dari bahan utama yaitu ikan kembung yang diperoleh dari Pasar Kedonganan dan sayur gonda (daun) yang berukuran besar yang diperoleh dari Pasar Badung. Bahan tambahan yang digunakan adalah tapioka, air es, putih telur, bawang putih, garam, dan merica. Bahan kimia untuk analisis antara lain tablet Kjeldahl, tetes PP (phenolphtalin), asam borat, $\mathrm{HCl}, \mathrm{NaOH}, \mathrm{H}_{2} \mathrm{SO}_{4}$, aquades, hexan, aseton, DPPH dan methanol.

Alat yang digunakan antara lain timbangan analitik (Shimadzu), pisau, sendok, blender (Miyako), panci, kompor, baskom, wajan, talenan, Spektrofotometer (Thermo Scientific Genesys 10S UV-Vis), erlenmayer (Pyrex), lumpang, oven (Memmert), kertas saring, labu lemak (Pyrex), cawan porselin, alumunium foil, desikator, pipet volume, gelas beaker (Pyrex), pipet tetes, labu ukur (Pyrex), tabung reaksi (Pyrex), corong, tabung reaksi (Pyrex), vortex (Maxi Mix II Type 367000) dan labu Kjeldahl.

\section{Rancangan Penelitian}

Penelitian dilakukan dengan menggunakan Rancangan Acak Lengkap (RAL) dengan perbandingan ikan kembung dan sayur gonda yang terdiri dari 6 taraf dan 3 kali ulangan pada masing-masing perlakuan sehingga diperoleh 18 unit percobaan. Taraf perlakuannya sebagai berikut:

$\mathrm{P} 0=100 \%$ ikan kembung : $0 \%$ sayur gonda $\mathrm{P} 1=95 \%$ ikan kembung : $5 \%$ sayur gonda P2 $=90 \%$ ikan kembung : $10 \%$ sayur gonda P3 $=85 \%$ ikan kembung : $15 \%$ sayur gonda $\mathrm{P} 4=80 \%$ ikan kembung : $20 \%$ sayur gonda P5 $=75 \%$ ikan kembung : $25 \%$ sayur gonda 
Data yang diperoleh dianalisis dengan sidik ragam dan apabila perlakuan berpengaruh terhadap variabel yang diamati maka dilanjutkan dengan uji Duncan (Gomez dan Gomez, 1995).

\section{Pelaksanaan Penelitian}

Persiapan bahan yang digunakan dalam pembuatan bakso yaitu, ikan kembung, sayur gonda, tapioka, bawang putih, bawang merah, garam, merica, putih telur, dan air es. Bahan yang digunakan kemudian ditimbang sesuai dengan formula. Formula bakso perbandingan sayur gonda dapat dilihat dapa Tabel 1.

Pelaksanaan penelitian ini dilakukan dengan dua tahap yaitu persiapan sayur gonda dan pembuatan bakso.

Tabel 1. Formulasi pembuatan bakso

\begin{tabular}{lllllll}
\hline Formulasi & P0 & P1 & P2 & P3 & P4 & P5 \\
\hline Daging ikan kembung (\%) & 100 & 95 & 90 & 85 & 80 & 75 \\
Sayur gonda (\%) & 0 & 5 & 10 & 15 & 20 & 25 \\
Tapioka (\%) & 35 & 35 & 35 & 35 & 35 & 35 \\
Bawang putih (\%) & 7 & 7 & 7 & 7 & 7 & 7 \\
Bawang merah (\%) & 9 & 9 & 9 & 9 & 9 & 9 \\
Garam (\%) & 4 & 4 & 4 & 4 & 4 & 4 \\
Merica (\%) & 1 & 1 & 1 & 1 & 1 & 1 \\
Putih telur (\%) & 10 & 10 & 10 & 10 & 10 & 10 \\
Es batu (\%) & 10 & 10 & 10 & 10 & 10 & 10 \\
\hline
\end{tabular}

Sumber : (Permatasari, 2002) yang dimodifikasi

Keterangan : \% bahan-bahan diatas berdasarkan jumlah ikan kembung dengan puree sayur gonda $(100 \mathrm{~g})$

\section{a. Persiapan sayur gonda}

Proses pembuatan puree sayur gonda dimulai dari proses sortasi yaitu pemisahan daun dengan dari batang. Kemudian dicuci dengan air yang mengalir. Setelah dilakukan proses pencucian, selanjutnya diblansing dengan cara direbus kurang lebih 3 menit dengan tujuan untuk menginaktifasi enzim. Sayur gonda yang telah diblansing kemudian disaring, lalu dihaluskan dengan blender sampai menjadi puree sayur gonda.

\section{b. Pembuatan Bakso}

Pembuatan bakso ikan mengacu pada prosedur (Permatasari, 2002). Bahan baku utama yang digunakan yaitu fillet ikan kembung yang sudah digiling menggunakan blander dan sayur gonda yang sudah dijadikan puree. Adapun langkah-langkah pembuatan bakso ikan dilakukan sebagai berikut: Langkah pertama, ikan difillet dipisahkan daging dari tulang dan kulitnya secara manual kemudian, ditimbang sesuai perlakuan dan selanjutnya dihaluskan menggunakan diblender sampai halus.

Proses selanjutnya yaitu ditambahkan puree sayur gonda, air es, bawang putih, bawang merah, merica, putih telur, garam dan tapioca sesuai perlakuan lalu dicampur hingga homogen. 
Selanjutnya, adonan dibentuk secara manual seperti bola-bola kecil kemudian direbus \pm 15 menit.

\section{Variabel yang diamati}

Variabel yang diamati dalam penelitian ini adalah analisis kadar air dengan metode pengeringan (Sudarmadji et al., 1997), kadar abu dengan metode pengabuan (Sudarmadji et al., 1997), kadar lemak dengan metode Soxhlet (Sudarmadji et al., 1997), kadar protein dengan metode Mikro-Kjeldahl (Sudarmadji et al., 1997), kadar karbohidrat dengan metode Carbohydrate by different (Sudarmadji et al., 1997), kadar total klorofil dengan metode Nollet (2004), kapasitas antioksidan dengan metode (Khan et al., 2012). dan sifat sensoris meliputi warna, tekstur, rasa, aroma, dan penerimaan keseluruhan (Soekarto 1985).

\section{HASIL DAN PEMBAHASAN}

\section{Karakteristik Bahan Baku Bakso}

Karakteristik ikan kembung dan sayur gonda sebagai bahan baku utama dalam pembuatan bakso dapat dilihat pada Tabel 2. Berikut rata-rata kadar air, kadar abu, kadar lemak, kadar protein, kadar karbohidrat, kadar total klorofil, dan kapasitas antioksidan dari sayur gonda dan ikan kembung.

Tabel 2. Karakteristik ikan kembung dan sayur gonda

\begin{tabular}{lcc}
\hline Komponen & Ikan Kembung & Sayur Gonda \\
\hline Kadar Air (\%) & 73,27 & 84,6 \\
Kadar Abu (\%) & 0,78 & 0,45 \\
Kadar Lemak (\%) & 6,52 & 4,33 \\
Kadar Protein (\%) & 18,93 & 5,61 \\
Kadar Karbohidrat (\%) & 0,5 & 5,01 \\
Kapasitas antioksidan (mg GAEAC/kg) & - & 51,91 \\
Kadar Total Klorofil (mg/kg) & - & 78,21 \\
\hline
\end{tabular}

Keterangan : Tanda (-) menunjukkan tidak dilakukan pengujian

\section{Karakteristik Bakso Ikan}

Nilai rata-rata kadar air, kadar abu, kadar lemak, kadar protein, pada bakso terdapat pada Tabel 3. Nilai rata-rata kadar karbohidrat, kapasitas antioksidan, dan total klorofil dari bakso terdapat pada Tabel 4.

\section{Kadar Air}

Hasil sidik ragam menunjukkan bahwa perbandingan ikan kembung dengan sayur gonda berpengaruh sangat nyata $(\mathrm{P}<0,01)$ terhadap kadar air bakso. Tabel 3 menunjukkan kadar air bakso berkisar antara 59,72\% sampai dengan 64,45\%. Kadar air bakso tertinggi diperoleh dari bakso pada perlakuan P5 yaitu 64,45\%, sedangkan kadar air bakso terendah diperoleh dari bakso pada perlakuan P0 yaitu 59,72\%. Pembuatan bakso dengan penambahan sayur gonda yang semakin meningkat menghasilkan bakso dengan kadar air yang semakin tinggi. Hal ini disebabkan karena kadar air sayur gonda 
lebih tinggi dibandingkan ikan kembung.

Berdasarkan analisis bahan baku (Tabel 2)

kadar air sayur gonda 84,6\% sedangkan

ikan kembung 73,27\%. Menurut SNI
7266:2014 kadar air maksimum untuk bakso maksimal $65 \%$ sehingga kadar air dari enam perlakuan telah memenuhi standar mutu bakso.

Tabel 3. Nilai rata-rata kadar air, kadar abu, kadar lemak, kadar protein, pada bakso

\begin{tabular}{cclll}
\hline $\begin{array}{c}\text { Ikan Kembung: } \\
\text { Sayur Gonda }\end{array}$ & Kadar Air $(\%)$ & Kadar Abu $(\%)$ & Kadar Lemak (\%) & Kadar Protein (\%) \\
\hline P0 $(100 \%: 0 \%)$ & $59,72 \pm 0,03 \mathrm{e}$ & $2,01 \pm 0,05 \mathrm{a}$ & $2,48 \pm 0,03 \mathrm{a}$ & $11,47 \pm 0,05 \mathrm{a}$ \\
P1 $(95 \%: 5 \%)$ & $61,06 \pm 0,02 \mathrm{~d}$ & $1,88 \pm 0,03 \mathrm{~b}$ & $2,09 \pm 0,01 \mathrm{~b}$ & $10,24 \pm 0,04 \mathrm{~b}$ \\
P2 $(90 \%: 10 \%)$ & $61,11 \pm 0,01 \mathrm{~d}$ & $1,73 \pm 0,02 \mathrm{~cd}$ & $2,02 \pm 0,01 \mathrm{c}$ & $10,16 \pm 0,04 \mathrm{c}$ \\
P3 $(85 \%: 15 \%)$ & $62,55 \pm 0,03 \mathrm{c}$ & $1,64 \pm 0,02 \mathrm{~d}$ & $1,99 \pm 0,01 \mathrm{~d}$ & $8,80 \pm 0,01 \mathrm{~d}$ \\
P4 $(80 \%: 20 \%)$ & $62,99 \pm 0,04 \mathrm{~b}$ & $1,56 \pm 0,03 \mathrm{~d}$ & $1,28 \pm 0,01 \mathrm{e}$ & $8,75 \pm 0,04 \mathrm{~d}$ \\
P5 (75\%:25\%) & $64,45 \pm 0,04 \mathrm{a}$ & $1,33 \pm 0,11 \mathrm{e}$ & $1,13 \pm 0,02 \mathrm{f}$ & $7,63 \pm 0,03 \mathrm{e}$ \\
\hline
\end{tabular}

Keterangan: Nilai rata-rata yang diikuti oleh huruf yang berbeda pada kolom yang sama menunjukkan berbeda nyata pada $\alpha 0.05(\mathrm{P}<0,05)$

Tabel. 4 Nilai Rata-rata Kadar Karbohidrat, Total Klorofil dan Kapasitas Antioksidan dari bakso

\begin{tabular}{llll}
\hline $\begin{array}{c}\text { Ikan Kembung: } \\
\text { Sayur Gonda }\end{array}$ & $\begin{array}{c}\text { Kadar Karbohidrat } \\
(\%)\end{array}$ & $\begin{array}{c}\text { Kadar Total } \\
\text { Klorofil }(\mathrm{mg} / \mathrm{kg})\end{array}$ & $\begin{array}{c}\text { Kapasitas Antioksidan } \\
(\mathrm{mg} \text { GAEAC/kg })\end{array}$ \\
\hline P0 $(100 \%: 0 \%)$ & $24,31 \pm 0,1 \mathrm{~d}$ & - & $4,1 \pm 0,64 \mathrm{f}$ \\
P1 $(95 \%: 5 \%)$ & $24,72 \pm 0,02 \mathrm{c}$ & $9,68 \pm 0,25 \mathrm{e}$ & $8,93 \pm 1,06 \mathrm{e}$ \\
P2 $(90 \%: 10 \%)$ & $24,98 \pm 0,02 \mathrm{~b}$ & $11,83 \pm 0,60 \mathrm{~d}$ & $17,13 \pm 0,32 \mathrm{~d}$ \\
P3 $(85 \%: 15 \%)$ & $25,03 \pm 0,05 \mathrm{~b}$ & $17,60 \pm 0,31 \mathrm{c}$ & $21,31 \pm 0,33 \mathrm{c}$ \\
P4 $(80 \%: 20 \%)$ & $25,43 \pm 0,03 \mathrm{a}$ & $18,39 \pm 0,14 \mathrm{~b}$ & $25,63 \pm 0,54 \mathrm{~b}$ \\
P5 $(75 \%: 25 \%)$ & $25,46 \pm 0,2 \mathrm{a}$ & $29,14 \pm 0,46 \mathrm{a}$ & $34,85 \pm 0,87 \mathrm{a}$ \\
\hline
\end{tabular}

Keterangan: Nilai rata-rata yang diikuti oleh huruf yang berbeda pada kolom yang sama menunjukkan berbeda nyata pada $\alpha 0.05(\mathrm{P}<0,05)$

\section{Kadar Abu}

Hasil sidik ragam menunjukkan bahwa perbandingan ikan kembung dengan sayur gonda berpengaruh sangat nyata $(\mathrm{P}<0,01)$ terhadap kadar abu bakso yang dihasilkan. Kadar abu bakso tertinggi diperoleh pada perlakuan P0 yaitu 2,01\%, sedangkan kadar abu terendah diperoleh pada perlakuan P5 yaitu 1,33\%. Semakin banyak penambahan sayur gonda maka kadar abu bakso yang dihasilkan semakin rendah. Hal ini disebabkan karena perbedaan kadar abu pada bahan baku dimana kandungan abu ikan kembung lebih tinggi daripada kandungan abu sayur gonda, yaitu ikan kembung sebesar 0,78\% dan sayur gonda $0,45 \%$. Sedangkan standar SNI kadar abu untuk produk bakso ikan yaitu maksimal 2\%. Kadar abu yang dihasilkan dari bakso dengan penambahan sayur gonda sesuai dengan standar maksimum SNI dari bakso ikan. Kadar abu dari produk bakso dengan penambahan sayur gonda ini masih memenuhi standar mutu SNI. Menurut Gaman et al., (1992), terjadi perubahan yang besar terhadap 
kandungan mineral selama proses pemasakkan, misalnya saja proses perebusan yang menyebabkan larutnya mineral ke dalam air. Mineral dapat dihilangkan dengan pelepasan atau pemisahan secara fisik. Sejumlah mineral memiliki kelarutan di dalam air. Secara umum, perebusan dalam air menyebabkan hilangnya mineral lebih banyak pada sayuran daripada pengukusan (Miller 1996).

\section{Kadar Protein}

Hasil sidik ragam menunjukkan bahwa perbandingan ikan kembung dengan sayur gonda berpengaruh sangat nyata $(\mathrm{P}<0,01)$ terhadap kadar protein bakso yang dihasilkan. Kadar protein bakso tertinggi diperoleh dari perlakuan P0 yaitu 11,47\%. Kadar protein terendah diperoleh dari perlakuan P5 yaitu 7,63\%. Kandungan protein mengalami penurunan dengan semakin banyak sayur gonda yang ditambahkan. Berdasarkan penelitian yang telah dilakukan terhadap bahan baku mentah, kadar protein pada daging ikan kembung sebesar 18,93\% dan kadar protein pada sayur gonda sebesar 5,61\%. Nilai kadar protein bakso ikan tersebut masih dapat diterima karena standar minimal berdasarkan SNI 7266:2014 adalah 7\%. Kandungan gizi seperti protein pada ikan dapat berkurang selama pengolahan. Hal ini dapat terjadi karena selama proses perebusan ikan terendam dalam air sehingga beberapa zat gizi larut air seperti protein ikut terlarut dalam air perebusan. Faktor yang mempengaruhi kehilangan zat gizi selama proses perebusan adalah luas permukaan bahan, konsentrasi zat terlarut dalam air perebusan dan adanya pengadukan air (Harris dan Karmas, 1989).

\section{Kadar Lemak}

Hasil sidik ragam menunjukkan bahwa perbandingan ikan kembung dengan sayur gonda berpengaruh sangat nyata $(\mathrm{P}<0,01)$ terhadap kadar lemak bakso yang dihasilkan. Kadar lemak bakso tertinggi diperoleh pada perlakuaan P0 yaitu 2,48\% sedangkan kadar lemak terendah diperoleh pada perlakuan P5 yaitu 1,13\%. Hal ini disebabkan semakin meningkan konsentrasi sayur gonda yang digunakan, maka lemak bakso yang dihasilkan semakin rendah. Berdasarkan analisis bahan baku lemak sayur gonda sebesar 4,33\% sedangkan ikan kembung 6,52\%. Nilai kadar lemak tersebut masih dapat diterima, karena standar minimal kadar lemak bakso ikan berdasarkan SNI 7266:2014 adalah 1\%.

\section{Kadar Karbohidrat}

Hasil sidik ragam menunjukkan bahwa perbandingan ikan kembung dengan sayur gonda berpengaruh sangat nyata $(\mathrm{P}<0,01)$ terhadap kadar karbohidrat bakso yang dihasilkan. Kadar karbohidrat tertinggi diperoleh pada perlakuan P5 yaitu 25,46\% sedangkan kadar karbohidrat terendah diperoleh pada perlakuan P0 yaitu $24,31 \%$. Kandungan karbohidrat bakso mengalami kenaikan dengan semakin 
banyak penggunaan sayur gonda. Menurut Sugito dan Hayati (2006) dalam Fatkurahman et al., (2012), menyatakan bahwa kadar karbohidrat yang dihitung secara by difference dipengaruhi oleh komponen nutrisi lain, semakin rendah komponen nutrisi lain maka kadar karbohidrat akan semakin tinggi. Begitu juga sebaliknya semakin tinggi komponen nutrisi lain maka kadar karbohidrat akan semakin rendah. Komponen nutrisi yang mempengaruhi besarnya kandungan karbohidrat diantaranya adalah kandungan protein, lemak, air dan abu.

\section{Kadar Total Klorofil}

Hasil sidik ragam menunjukkan bahwa perbandingan ikan kembung dengan sayur gonda berpengaruh sangat nyata $(\mathrm{P}<0,01)$ terhadap total klorofil bakso.

Tabel 4 menunjukkan bahwa total klorofil bakso berkisar $0 \mathrm{mg} / \mathrm{kg}$ sampai dengan $29,14 \mathrm{mg} / \mathrm{kg}$. total klorofil tertinggi diperoleh pada perlakuan P5 yaitu $29,14 \mathrm{mg} / \mathrm{kg}$, sedangkan total klorofil bakso terendah diperoleh pada perlakuan P0 yaitu $0 \mathrm{mg} / \mathrm{kg}$. Pembuatan bakso dengan penambahan sayur gonda yang semakin meningkat menghasilkan bakso dengan total klorofil yang semakin tinggi. Hal ini disebabkan karena total klorofil sayur gonda lebih tinggi dibandingkan total klorofil ikan kembung. Berdasarkan analisis bahan baku (Tabel 2) total klorofil sayur gonda adalah $78,21 \mathrm{mg} / \mathrm{kg}$, sedangkan total klorofil ikan kembung yaitu $0 \mathrm{mg} / \mathrm{kg}$.

\section{Kapasitas Antioksidan}

Hasil analisis ragam menunjukkan bahwa perbandingan ikan kembung dengan sayur gonda pada bakso berpengaruh sangat nyata $\quad(\mathrm{P}<0,01) \quad$ terhadap kapasitas antioksidan. Nilai rata-rata kapasitas antioksidan bakso dengan perbandingan ikan kembung dan sayur gonda gonda berkisar antara 4,1 mg GAEAC/kg sampai 34,85 mg GAEAC/kg. Semakin banyak penambahan sayur gonda yang ditambahkan maka semakin tinggi nilai kapsitas antioksidan bakso yang dihasilkan. Berdasarkan analisis bahan baku nilai kapsitas antioksidan sayur gonda yaitu 58,19 mg GAEAC/kg, sedangkan nilai kapsitas antioksidan ikan kembung yaitu 0 mg GAEAC $/ \mathrm{kg}$. Menurut Carlsen et al. (2010) pangan nabati secara signifikan memiliki kandungan antioksidan yang lebih tinggi dari pada pangan hewani.

\section{Sifat Sensoris}

Sifat sensoris bakso dilakukan dengan uji hedonik terhadap warna, tekstur, aroma, rasa, dan penerimaan keseluruhan serta uji skoring terhadap warna dan tekstur. Nilai rata-rata uji hedonik terhadap warna, tekstur, aroma, rasa, dan penerimaan keseluruhan bakso dapat dilihat pada Tabel 5 serta nilai rata-rata uji skoring terhadap warna dan tekstur dapat dilihat pada tabel 6 . 
Tabel 5. Nilai Rata-rata Uji hedonik Warna, Tekstur, Aroma, Rasa, dan Penerimaan keseluruhan

\begin{tabular}{llllll}
\hline $\begin{array}{l}\text { Ikan Kembung: Sayur } \\
\text { Gonda }\end{array}$ & Warna & Tekstur & Aroma & Rasa & $\begin{array}{l}\text { Penerimaan } \\
\text { keseluruhan }\end{array}$ \\
\hline P0 $(100 \%: 0 \%)$ & $4,3 \mathrm{c}$ & $4,8 \mathrm{ab}$ & $5,1 \mathrm{ab}$ & $4,7 \mathrm{a}$ & $4,4 \mathrm{c}$ \\
P1 $(95 \%: 5 \%)$ & $4,7 \mathrm{bc}$ & $4,4 \mathrm{~b}$ & $5,4 \mathrm{ab}$ & $5,4 \mathrm{a}$ & $5,35 \mathrm{ab}$ \\
P2 $(90 \%: 10 \%)$ & $4,95 \mathrm{bc}$ & $5,1 \mathrm{ab}$ & $5,35 \mathrm{ab}$ & $5,4 \mathrm{a}$ & $5,45 \mathrm{ab}$ \\
P3 $(85 \%: 15 \%)$ & $5,05 \mathrm{ab}$ & $4,95 \mathrm{ab}$ & $5,5 \mathrm{ab}$ & $5,2 \mathrm{a}$ & $5,3 \mathrm{ab}$ \\
P4 $(80 \%: 20 \%)$ & $5,7 \mathrm{a}$ & $5,25 \mathrm{a}$ & $5,6 \mathrm{a}$ & $5,5 \mathrm{a}$ & $5,7 \mathrm{a}$ \\
P5 $(75 \%: 25 \%)$ & $5,2 \mathrm{ab}$ & $4,85 \mathrm{ab}$ & $4,8 \mathrm{~b}$ & $4,95 \mathrm{a}$ & $4,95 \mathrm{~b}$ \\
\hline
\end{tabular}

Keterangan: Nilai rata-rata yang oleh huruf yang berbeda pada kolom yang sama menunjukkan perlakuan berbeda nyata $\alpha 0.05(\mathrm{P}<0,05)$

Tabel 6. Nilai Rata-rata Uji Skoring Warna

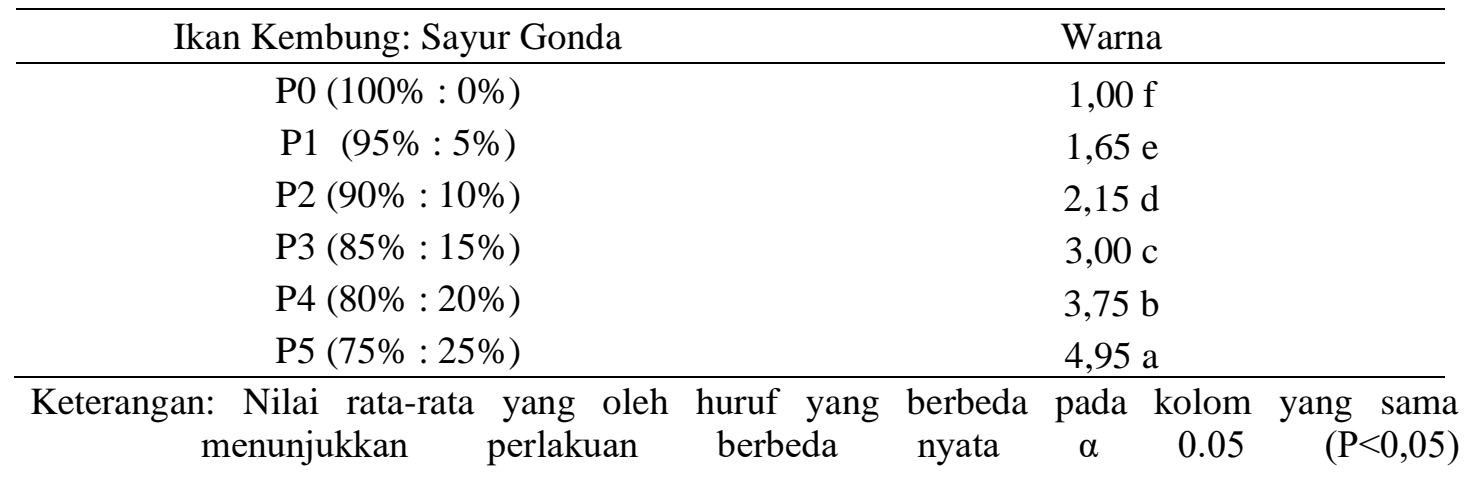

\section{Warna}

Berdasarkan data hasil sidik ragam menunjukkan bahwa perbandingan ikan kembung dan sayur gonda berpengaruh sangat nyata $(\mathrm{P}<0,01)$ terhadap warna (uji hedonik dan uji skoring) bakso. Tabel 5 menunjukkan bahwa nilai hedonik terhadap warna bakso berkisar antara 4,3 (biasa) sampai 5,7 (suka). Nilai hedonik warna tertinggi diperoleh dari bakso pada perlakuan P4 serta berbeda tidak nyata dengan perlakuan P3 dan P5. Nilai hedonik warna terendah diperleh pada perlakuan P0 serta berbeda tidak nyata pada perlakuan P1 dan P2. Semakin hijau warna bakso yang dihasilkan maka semakin tinggi nilai kesukaan panelis terhadap warna bakso.
Tabel 6 menunjukkan bahwa nilai skoring terhadap warna bakso berkisar antara 1 (putih keabu-abuan) sampai 4,95 (hijau pekat). Nilai skoring wana tertinggi bakso diperoleh pada perlakuan P5 yaitu 4,95 (hijau pekat) dan nilai terendah diperoleh pada perlakuan P0 yaitu 1 (putih keabuabuan). Makin banyak penambahan sayur gonda maka bakso akan berwarna hijau, hal ini disebabkan karena sayur gonda mengandung senyawa klorofil. Klorofil menyebabkan warna hijau pudar sampai hijau pekat. Menurut Muchtadi et al., (2011) sayuran hijau banyak mengandung pigmen klorofil, biasanya terdapat pada daun dan permukaan batang tanaman. Penambahn sayur gonda dapat berfungsi 
sebagai pewarna alami sehingga dapat menghasilkan bakso dengan warna yang lebih menarik.

\section{Tekstur}

Hasil sidik ragam menunjukkan bahwa perbandingan ikan kembung dengan sayur gonda tidak berpengaruh nyata $(\mathrm{P}>0,05)$ terhadap uji hedonik tekstur bakso. Tabel 5 menunjukkan bahwa nilai rata-rata tingkat kesukaan panelis terhadap tekstur bakso berkisar antara 4,4 (biasa) sampai degan 5,25 (agak suka). Perbandingan ikan kembung dengan sayur gonda tidak berpengaruh secara signifikan terhadap penilaian panelis pada tekstur bakso yang dihasilkan.

\section{Aroma}

Hasil sidik ragam menunjukkan bahwa perbandingan ikan kembung dengan sayur gonda tidak berpengaruh nyata $(\mathrm{P}>0,05)$ terhadap kesukaan aroma bakso. Tabel 5 menunjukkan bahwa nilai rata-rata kesukaan panelis berkisar antara 4,8 (agak suka) sampai dengan 5,6 (suka). Perbandingan ikan kembung dengan sayur gonda tidak berpengaruh secara signifikan terhadap penilaian panelis pada aroma bakso yang dihasilkan.

\section{Rasa}

Hasil sidik ragam menunjukkan bahwa perbandingan ikan kembung dengan sayur gonda tidak berpengaruh nyata $(\mathrm{P}>0,05)$ terhadap kesukaan rasa bakso.

Tabel 5 menunjukkan bahwa nilai rata-rata kesukaan panelis berkisar antara 4,7 (agak suka) sampai dengan 5,5 (suka). Tingginya konsentrasi sayur gonda pada bakso ikan tidak berpengaruh secara signifikan terhadap rasa karena penambahan ikan kembung lebih mendominasi rasa dari bakso yang dihasilkan.

\section{Penerimaan Keseluruhan}

Hasil sidik ragam menunjukkan bahwa perbandingan ikan kembung dengan sayur gonda berpengaruh sangat nyata $(\mathrm{P}<0,01)$ terhadap penerimaan keseluruhan dari bakso. Tabel 5 menunjukkan bahwa nilai hedonik terhadap penerimaan keseluruhan bakso berkisar antara 4,4 (biasa) sampai dengan 5,7 (suka). Nilai hedonik penerimaan keseluruhan terendah diperoleh pada perlakuan P0 yaitu 4,4 (biasa) sedangkan nilai tertinggi pada perlakuan P4 yaitu 5,7 (suka) serta berbeda tidak nyata dengan perlakuan $\mathrm{P} 1, \mathrm{P} 2$, dan P3. Penerimaan keseluruhan bakso dipengaruhi oleh beberapa faktor seperti warna, tekstur, aroma, dan rasa.

\section{KESIMPULAN DAN SARAN}

\section{Kesimpulan}

Berdasarkan hasil penelitian yang telah dilakukan dapat diambil kesimpulan sebagai berikut:

1. Perbandingan ikan kembung dengan sayur gonda berpengaruh sangat nyata terhadap kadar air, kadar abu, kadar lemak, kadar protein, kadar karbohidrat, kadar klorofil, kapasitas antioksidan, warna (hedonik dan 
skoring), dan penerimaan keseluruhan serta tidak berpengaruh nyata terhadap aroma, tekstur dan rasa.

2. Perbandingan $80 \%$ ikan kembung: $20 \%$ sayur gonda menghasilkan karakteristik terbaik bakso dengan kriteria kadar air $62,99 \%$, kadar abu 1,56\%, kadar lemak 1,28\%, kadar protein $8,75 \%$, kadar karbohidrat $25,45 \%$, kadar total klorofil 18,39\%, dan kapasitas antioksidan $25,63 \%$. Sifat sensoris yang diperoleh yaitu warna (hijau agak pekat, disukai), tekstur (agak disukai), aroma (disukai), rasa (disukai), dan penerimaan keseluruhan (disukai).

\section{Saran}

Berdasarkan hasil penelitian ini disarankan untuk menggunakan perbandingan $80 \%$ ikan kembung : 20\% sayur gonda pada proses pembuatan bakso ikan dan disarankan untuk penelitian selanjutnya menggunakan jenis sayur yang berbeda untuk mengetahui perubahan fisik dan kimiawi dari bakso ikan.

\section{DAFTAR PUSTAKA}

Badan Standarisasi Nasional. 2014. Bakso Daging. SNI 7226-2014. Badan Standarisasi Nasional. Jakarta.

Carlsen M, Halvorsen B, Holte K, Bohn S, Dragland S, Sampson L, Willey C, Senoo H, Umezono Y, Sanada C et al. 2010. The total antioxidant content of more than 3100 foods, beverages, spices, herbs and supplements used worldwide. Nutrition Journal. 9(3).
Cintari, L., A A N. Antarini, I A E. Padmiari, dan I B K. W. Yoga. 2013. Identifikasi Senyawa Aktif Ekstrak Etanol Sayur Gonda (Sphenoclea zeylanica) dan Potensinya Sebagai Antioksidan. Jurnal Skala Husada. 10 (2). (September). 126 - 135.

Fatkurahman, R., Atmaka, W., dan Basito. 2012. Karakteristik Sensoris dan Sifat Fisikokimia Cookies dengan Subtitusi Bekatul Beras Hitam (Oryza sativa L.) dan Tepung Jagung (Zea mays L.). Jurnal Teknosains Pangan 1(1).

Gaman PM dan Sherrington KB. 1992. Pengantar Ilmu Pangan, Nutrisi dan Mikrobiologi.UGMPress. Yogykart a.

Gomez, K. A. dan A. A. Gomez. 1995. Prosedur Statistik Untuk Penelitian Pertanian. UI Press. Jakarta.

Harris RS dan Karmas E. 1989. Evaluasi Gizi pada Pengolahan Bahan Pangan. ITB Press. Bandung.

Haryati, S., Sya'rani, L., dan Agustini, T. 2006. Kajian Subtitusi Tepung Ikan Kembung, Rebon, Rajungan dalam Berbagai Konsentrasi, Terhadap Mutu Fisika-Kimiawi dan Organoleptik Pada Mie Instan. Jurnal Pasir Laut 2(1): 37-51.

Khan, dan Rahmat Ali. 2012. Evaluation of flavonoids and diverse antioxidant activities of Sonchus arvensis. Chemistry Central Journal. 6:126

Koswara, S., Hariyadi, P. dan Purnomo, E.H. 2001. Teknologi Pangan dan Agroindustri. UI Press. Jakarta.

Lawang, A.T. 2013. Pembuatan Dispersi Konsentrat Ikan Gabus (Ophiocephalus Striatus) Sebagai Makanan Tambahan (Food Supplement). Universitas Hasanuddin. Makassar. 
Miefthawati, N., Gusrina, L dan Axena, F. 2013. Penetapan Kadar Kalsium pada Ikan Kembung Segar dan Ikan Kembung Asin Secara Kompleksometri. Jurnal Analisis Kesehatan Klinika Sains 1(1).

Miller AL. 1996. Antioxidant flavonoid structural usage alternative medical. Jurnal Flavonoid.

Muchtadi, T.R dan Sugiyono. 2013. Prinsip Proses Dan Teknologi Pangan. Alfabeta : Bandung.

Mulyadi, A. F., S. Wijana dan Y. Hastuti. 2014. Studi Proses Pengolahan Pasta Mangga Podang Urang (Mangifera indica L.) (Kajian Konsentrasi Dekstrin dan Metode Pengawetan Termal). PS Teknologi Industri Pertanian, Fakultas Teknologi Pertanian. Universitas Brawijaya

Nollet, LML. 2004. Handbook of Food Analysis Physical Characterzati-ion and Nutrient Analysis. Marcel Dekker. Inc. 1 (2). New York.

Nurhadi, B. 2011. Manfaat yang terkandung dalam warna warni makanan. [Skripsi]. Bandung: Fakultas Teknologi Industri Pertanian Universitas Padjadjaran.

Permatasari, W.A. 2002. Kandungan Gizi Bakso Campuran Daging Sapi dengan Jamur Tiram Putih (Pleuotus ostreatus) pada Taraf yang Berbeda. [Skripsi]: Ilmu Produksi Ternak. Fakultas Perternakan, Institut Pertanian Bogor.

Rajagukguk dan Merlin. 2011. Pengaruh Kombinasi Tepung Tempe Kedelai Dan Tepung Ikan Kembung (Rastrelliger Kanagurta) Jantan Terhadap Kualitas Cookies. Thesis. Universitas Atmajaya Yogyakarta.
Santoso, J., Ling, F., dan Handayani, R. 2011. Pengaruh Pengkomposisian dan Penyimpanan Dingin Terhadap Perubahan Karakteristik Surimi Ikan Pari (Trygon sp.) dan Ikan Kembung (Rastrelliger sp.). Jurnal Akuatika 2(2).

Sari, F., Rachmawanti, D., dan Rahadian, D. 2013. Kajian Karakteristik Sensoris Dan Kimia Sala Lauak Dengan Bahan Dasar Beberapa Macam Ikan Dan Tepung Beras (Oryza Sativa) Sebagai Pelengkap Makanan Pada Anak Autis. Jurnal Teknosains Pangan 2(3).

Soekarto, 1985. Penilaian Organoleptik untuk Industri Pangan dan Hasil Pertanian. Pusat Pengembangan Teknologi Pangan, IPB. Bogor.

Sudarmadji, S., dan Suhardi. 1997. Prosedur Analisa untuk Bahan Makanan dan Pertanian. Liberty. Yogyakarta

Thariq, A. S., Swastawati, F., dan Surti, T., 2014. Pengaruh Perbedaan Konsentrasi Garam Pada Peda Ikan Kembung (Rastrelliger sp) Terhadap Kandungan Asam Glutamat Pemberi Rasa Gurih (Umami). Program Studi Teknolog Hasil Perikanan. Fakultas Perikanan dan Ilmu Kelautan. Universitas Diponegoro. Semarang.

Winarno, F.G. dan T.S. Rahayu. 1994. Bahan Tambahan untuk Makanan dan Kontaminan. Pustaka Sinar Harapan. Jakarta. 